\title{
Kebutuhan Spiritual pada Pasien Kanker
}

\author{
Aan Nuraeni, Ikeu Nurhidayah, Nuroktavia Hidayati, Citra Windani Mambang Sari, \\ Ristina Mirwanti \\ Fakultas Keperawatan Universitas Padjadjaran \\ E-mail:aan.nuraeni@fkep.unpad.ac.id
}

\begin{abstract}
Abstrak
Spiritual care merupakan hal yang penting bagi pasien kanker. Namun pelayan keperawatan masih terfokus pada aspek fisik, sehingga data mengenai kebutuhan spiritual pasien kanker di Indonesia belum komprehensif. Penelitian ini bertujuan mengidentifikasi kebutuhan spiritual pada pasien kanker serta tingkat kebutuhannya. Penelitian deskriptif kuantitatif ini melibatkan 76 pasien kanker yang sedang menjalani perawatan di salah satu RS di Bandung yang diambil dengan accidental sampling. Data dikumpulkan dengan menggunakan instrumen Spiritual Needs Questionaire 2.1 (SPNQ 2.1) yang meliputi aspek religi, kedamaian dan eksistensi diri. Analisa data kebutuhan spiritualitas menggunakan distribusi frekuensi dan persentase, sedangkan nilai rerata digunakan untuk mengidentifikasi seberapa kuat kebutuhan spiritual tersebut bagi responden dengan kategori 1 - 1,9 agak dibutuhkan; 2-2,9 dibutuhkan; 3 sangat dibutuhkan. Hasil penelitian menunjukkan bahwa pada aspek religi, berdoa dengan orang lain dan seseorang berdoa untuk responden memiliki persentase paling tinggi (96,05\%). Pada aspek kedamaian, tinggal di tempat yang tenang dan damai serta menemukan kedamaian batin memiliki persentase paling tinggi $(89,47 \%)$. Pada aspek eksistensi diri, menemukan makna dalam sakit dan penderitaan memiliki persentase paling tinggi (94,74\%). Adapun pada kebutuhan untuk memberi, beralih menjadi orang yang penuh cinta kasih memiliki persentase paling tinggi $(89,47 \%)$. Kebutuhan tersebutmasuk ke dalamkategori dibutuhkan dengannilairerata sebagai berikut : kebutuhan religi $(2,28 \pm 0,47)$; kedamaian $(2,19 \pm 0,47)$; eksistensi diri $(2,11 \pm 0,76)$; dan kebutuhan untuk memberi $(2,08 \pm 0,55)$. Penelitian ini menunjukkan bahwa semua dimensi kebutuhan spiritual sangat dibutuhkan oleh responden, dan kebutuhan religi merupakan kebutuhan yang paling banyak dipilih dan dirasakan paling dibutuhkan.
\end{abstract}

Kata kunci: Kanker, kebutuhan spiritual, pasien.

\section{Spiritual Needs of Patients with Cancer}

\begin{abstract}
Cancer affects a patient's various life aspects, physical, psychological, as well as spiritual. However, more often than not, nursing care focuses only on the physical aspect, and neglects the spiritual side. This study aimed to identify the types and levels of spiritual needs affecting cancer patients. This quantitative descriptive study involved 76 cancer patients, selected using accidental sampling method, who were undergoing treatment in a hospital in Bandung, West Java. Data were collected using Spiritual Needs Questionnaire 2.1 (SPNQ 2.1) consisting of Religious, Inner Peace, Existential, and Actively Giving aspects. To analyse data of spiritual needs, the study used distribution of frequency and percentage. Mean value was used to identify how important those spiritual needs were to respondents (1-1.9: somewhat needed, 2-2.9: fairly needed, 3: strongly needed). The results showed that on Religious aspect, "praying with others" and "having someone pray for me" have the highest percentage (96.05\%). On Inner Peace, "living in a calm and peaceful place" and "finding inner peace" have the highest precentage (89.47\%). On Existential aspect, "finding meaning in pain and suffering" has the highest percentage $(94.74 \%)$. On Actively Giving, "becoming a loving person" has the highest percentage (89.47\%). Those needs were identified as "fairly needed", with the following mean values: Religious $(2.28 \pm 0.47)$, Inner Peace (2.19 \pm 0.47$)$, Existential $(2.11 \pm 0,76)$, and Actively Giving $(2.08 \pm 0,55)$. This study indicated all dimensions of spiritual aspects were needed by respondents and religious aspects were most needed.
\end{abstract}

Key words: Cancer, patient, spiritual needs. 


\section{Pendahuluan}

World Health Organization (WHO) (2010) memperkirakan kasus kanker akan terus mengalami peningkatan dan diprediksi akan mencapai 21,4 juta kasus pada tahun 2030 dan dua pertiga kasus tersebut terdapat di negaranegara berkembang seperti di Indonesia. Di Indonesia berdasarkan hasil survey Riset Kesehatan Dasar tahun 2013 didapatkan prevalensi penyakit tumor/kanker mencapai 1,4 per mil (Kemenkes RI, 2013).

Penyakit kanker berdampak terhadap seluruh aspek kehidupan penderita, baik fisik, psikologis maupun spiritual. Secara fisik penderita akan mengalami nyeri, fatigue, serta penurunan fungsi fisik dan kelelahan yang dirasakan terus menerus (Ahn et al., 2009; Grimsbø, Ruland, dan Finset, 2012), kondisi ini akan mengakibatkan timbulnya masalah psikologis pada pasien. Respon psikologis yang sering terjadi pada panderita kanker antara lain sedih, syok, apatis, berduka, cemas, takut terhadap kekambuhan maupun kematian, harga diri rendah, persepsi diri rendah, penurunan gambaran diri, isolasi diri dan depresi (Brown et al., 2005; Limpscomb, Gotay, dan Snyder, 2005; Sjamsuhidajat \& Wim de Jong, 2004, Van Weert, 2007; Braeken et al., 2009; Hamid, 2009; Machin, 2009; Grimsbø, Ruland, dan Finset, 2012) selain itu menurut Roos (2002), Peterson dan Bredow (2009), Martz dan Livneh (2007), respon lain yang dapat muncul pada penderita kanker adalah merasa kehilangan dan merasakan penderitaan yang berkelanjutan.

Masalah yang dialami oleh pasien kanker meliputi seluruh aspek yakni aspek fisik, psikologis, sosial dan spiritual, Meskipun masalah yang dihadapi pasien kanker kompleks, upaya yang dilakukan oleh pemberi pelayanan kesehatan masih terfokus pada penanganan penyakit atau permasalan fisik saja. Pada pasien kanker, terutama kanker stadium lanjut, upaya penyembuhan menjadi sangat sulit, sedikit sekali pasien yang dapat kembali pulih dari penyakitnya. Di sisi lain, pasien merasakan pentingnya pemenuhan kebutuhan spiritual.

Pasien dengan kondisi terminal seperti ini, hal yang dianggap sangat berharga adalah spiritual. Menurut Murray (2004), spiritual care pada pasien dengan penyakit terminal dirasakan oleh pasien sebagai hal yang penting. Sejalan dengan itu, Mok, Wong, dan Wong (2009) menyatakan bahwa satusatunya sumber penyembuhan (healing) bagi pasien dengan penyakit terminal adalah spiritualitas mereka. Pasien membutuhkan intervensi spiritual dengan porsi yang cukup besar, selain pengobatan ataupun perawatan fisik (Mcgrath, 2004). Menurut Guillory, Sowell, Moneyham, dan Seals (1997), pasien dengan penyakit terminal akan lebih mencari makna dari kehidupan sebagai cara untuk memperpanjang kelangsungan hidup mereka. Ketika tidak ada lagi cara untuk sembuh, perhatian pasien akan terfokus pada pemahaman terhadap proses kehidupan dan keterikatan dengan kekuatan yang lebih tinggi.

Pentingnya pemenuhan kebutuhan spiritual juga diperkuat oleh Puchalski (2009) yang menyatakan bahwa tidak semua penyakit dapat disembuhkan namun selalu ada ruang untuk "healing"atau penyembuhan. Penyembuhan dapat dimaknai sebagai penerimaan terhadap penyakit dan ketentraman dalam kehidupan danspiritual menjadi inti dari penyembuhan". Dalam penelitian lainnya Puchalski et al (2009) mengungkapkan bahwa penyembuhan mengacu pada kemampuan seseorang mendapatkan kebahagiaan, kenyamanan, koneksi, makna, dan tujuan hidup dalam penderitaan maupun rasa sakit yang dialami.

Dalam menunaikan perannya, sebagai care provider perawat harus melihat pasien secara holistik. Meski demikian, Dossey, Keegan, dan Guzzetta (2005) menyatakan bahwa salah satu tantangan besar perawat saat ini adalah mengintegrasikan konsep dari teknologi body, mind and spirit kedalam praktek Keperawatan. Adapun sebagai tenaga kesehatan, perawat dalam memulai mengintegrasikan spiritualitas ke dalam praktek pelayanan kesehatan dapat melalui tiga cara, yakni: 1). Melalui berbagai penelitian; 2). Melalui pengkajian spiritualitas pasien dan nyeri spiritual yang dialami pasien dan 3). Melalui intervensi terapeutik (Anandarajah dan Hight, 2001). Pemenuhan kebutuhan spiritual pada pasien tidak hanya bermanfaat bagi pasien saja tetapi dapat berdampak terhadap profesionalisme kerja 
perawat (Kociszewski, 2004) dan pelayanan kesehatan. Hodge, Sun, dan Wolosin (2014) menyebutkan bahwa terdapat hubungan positif antara kebutuhan spiritual dengan kepuasan pelayanan kesehatan.

Upaya pemenuhan kebutuhan spiritual pasien diawali dengan kajian kebutuhan spiritual. Berdasarkan kajian tersebut perawat dapat mengetahui kebutuhan spiritual mana yang perlu dan belum terpenuhi pada pasien, karena spiritual bagi setiap orang berbeda, tergantung dari cara pandang dan latar belakang seseorang. Menurut Hawari (2004) serta Burkhardt dan Nagai-Jacobson (2005), spiritualitas bersifat personal atau individual. Terdapat berbagai hal yang melatarbelakanginya, yang mana setiap individu memiliki cara pandang dan pemahaman tersendiri tentang spiritualitas. Perbedaan konsep spiritual dipengaruhi oleh budaya, perkembangan, pengalaman hidup dan persepsi seseorang tentang hidup dan kehidupan.

Berdasarkan hasil observasi dan wawancara yang dilakukan terhadap perawat yang memberikan layanan keperawatan kepada pasien-pasien dengan penyakit terminal di sebuahn RS di Kota Bandung diketahui bahwa selama ini spiritual care yang biasa dilakukan masih sangat terbatas. Saat ini, perawat belum secara optimal memberikan pemenuhan kebutuhan spiritual pasien. Sebagian besar perawat masih memiliki persepsi bahwa pemenuhan kebutuhan spiritual dilakukan dalam bentuk fasilitasi ibadah keagamaan dan tidak semua pasien mendapatkannya. Pemahaman yang berkembang mengenai spiritual care di Indonesia sangat kental dengan praktekpraktek religius keagamaan, seperti mentalkinkan pasien dying, membacakan ayat-ayat Al-Quran ataupun kitab suci lainnya dan berdoa. Hal ini diperkuat oleh penelitian lain yang menunjukkan bahwa persepsi perawat tentang cara/bentuk pemenuhan kebutuhan spiritual kepada pasien masih terbatas pada membantu kegiatan ibadah pasien, melibatkan keluarga dan tokoh agama serta memberikan semangat (Ariyani, Suryani dan Nuraeni ,2014). Padahal dalam berbagai penelitian keperawatan konsep spiritual care ternyata lebih luas dari hanya praktek keagamaan saja, tetapi berhubungan juga dengan arti dari keberadaan manusia. Berdasarkan uraian tersebut menjadi penting untuk meneliti lebih lanjut tentang kebutuhan spiritual dari pasien dengan kanker stadium lanjut yang menjalani perawatan di unit rawat inap salah satu rumah sakit di Bandung.

\section{Metode Penelitian}

Penelitian ini menggunakan rancangan deskriptif kuantitatif. Peneliti akan menguji data yang dikumpulkan pada satu kesempatan dengan subjek yang sama (coss sectional). Peneliti memaparkan variabel penelitian yang diteliti untuk mendapatkan pemahaman yang mendalam tentang fenomena.

Populasi pada penelitian ini adalah pasien kanker yang dirawat di ruang rawat inap salah satu rumah sakit di Bandung dengan jumlah rata-rata per bulan 120 pasien. Sampel pada penelitian ini adalah pasien kanker dewasa dengan menggunakan teknik pengambilan sampel insidental sampling. Ukuran sampel ditentukan dengan menggunakan rumus (Nugraha, 2007). Populasi $\mathrm{N}=120$ yang didapatkan berdasarkan rata-rata pasien kanker yang dirawat 40 orang pasien per bulan di setiap ruang rawat inap, derajat kesalahan $\mathrm{e}=10 \%$, maka ukuran sampel (n) yang diperlukan dalam penelitian ini adalah minimal 55 subjek. Dalam penelitian ini jumlah calon responden yang berhasil direkrut sebanyak 100 orang, namun hanya 76 responden saja yang mengisi kuesioner dengan lengkap dan dapat dilanjutkan ke dalam tahapan analisis data.

Instrumen yang digunakan dalam penelitian ini adalah Spiritual Needs Questionaire (SpNQ) yang dikembangkan oleh Bussing, Balzat, dan Heusser, (2010). Instrumen ini digunakan untuk mengukur kebutuhan spiritualitas khususnya pada pasien dewasa yang mengalami sakit kronis. Terdiri atas 19 item pertanyaan. Dalam instrumen kebutuhan spiritualitas ini, ada empat bagian yaitu, religious; inner peace; existential (reflection/rerataing); dan actively giving/ generativity. Dalam hal skoring, pertamatama instrumen ini akan menilai kebutuhan spiritual responden (ya/tidak), selanjutnya 
menilai seberapa kuat/penting kebutuhan spiritual tersebut bagi mereka dengan menggunakan skala 1-3 (1- agak dibutuhkan; 2- dibutuhkan; 3- sangat dibutuhkan).

Validitas dari instrumen, dijelaskan bahwa Aspek kebutuhan religi berhubungan sangat kuat dengan skala SpREUK ( $r>0.7)$ dan juga berhubungan kuat dengan Search for Support/ Access and Reflection (Positive Interpretation of Disease). Kebutuhan eksistensi diri dan kebutuhan untuk memberi berhubungan dengan skala SpREUK, sementara kebutuhan kedamaian berhubungan lemah. Pada pasien dengan kondisi nyeri kronik, kebutuhan eksistensi diri berhubungan dengan strategi escape-avoidance (Escape from illness). Kebutuhan spiritual berhubungan lemah dengan kepuasan hidup, sementara itu kebutuhan untuk memberi berhubungan dengan kepuasan hidup $(\mathrm{r}=0.17 ; \mathrm{p}=0.12)$ dan berhubungan terbalik dengan skor gejala pasien $(\mathrm{r}=-0.29 ; \mathrm{p}<0.0001)$. Kebutuhan kedamaian berhubungan lemah dengan kepuasan pasien terhadap efikasi pengobatan $(\mathrm{r}=0.24 ; \mathrm{p}<0.0001)$. Analisis regresi linier multivariat menunjukkan bahwa kecemasan memiliki dampak signifikan pada kebutuhan kedamaian, kebutuhan eksistensi diri, dan kebutuhan untuk memberi pada pasien kanker. Dan nilai reliabilitas kuesioner SpNQ 2.1 memiliki konsistensi internal yang diperkirakan antara 0.74 sampai dengan 0.92 .

\section{Hasil Penelitian}

Berdasarkan hasil penelitian, semua aspek dari kebutuhan spiritual dirasakan sebagai kebutuhan oleh sebagian besar responden, hanya sebagian kecil dari responden saja yang tidak membutuhkan aspek spiritual tertentu. Aspek kebutuhan spiritual yang dipilih oleh hamper sebagian besar responden adalah aspek kebutuhan religi.

Tabel 1 terlihat kebutuhan religi pada penelitian ini menjadi dimensi kebutuhan spiritual yang paling banyak dibutuhkan oleh hampir seluruh responden. Dari dimensi ini aspek yang paling banyak dibutuhkan adalah berdoa baik dengan orang lain atau didoakan oleh orang lain.

Kebutuhan akan kedamaian sebagian besar dipilih oleh responden sebagai salah

Tabel 1 Distribusi Kebutuhan Dimensi Religi pada Kebutuhan Spiritual Pasien Kanker $(n=76)$

\begin{tabular}{lcccc}
\hline \multicolumn{1}{c}{ Kebutuhan Religi } & Tidak & $\mathbf{( \% )}$ & Ya & (\%) \\
\hline Berdoa dengan orang lain & 3 & 3,05 & 73 & 96,05 \\
Seseorang berdoa untuk anda & 3 & 3,05 & 73 & 96,05 \\
Berdoa untuk diri sendiri & 3 & 3,05 & 73 & 96,05 \\
Beralih dan mendekat dalam keagungan akan kehadiran & 5 & 6,58 & 71 & 93,42 \\
yang lebih tinggi (keesaan, Tuhan, malaikat & & & & \\
Berpartisipasi dalam upacara keagamaan & 9 & 11,84 & 67 & 88,16 \\
Membaca buku keagamaan & 13 & 17,11 & 63 & 82,89 \\
\hline
\end{tabular}

Tabel 2 Distribusi Kebutuhan Dimensi Kedamaian pada Kebutuhan Spiritual Pasien Kanker $(n=76)$

\begin{tabular}{|c|c|c|c|c|}
\hline Kebutuhan Kedamaian & Tidak & $(\%)$ & Ya & $(\%)$ \\
\hline Tinggal di tempat yang tenang dan damai & 8 & 10,53 & 68 & 89,47 \\
\hline Menemukan kedamaian batin & 8 & 10,53 & 68 & 89,47 \\
\hline $\begin{array}{l}\text { Berbicara dengan orang lain mengenai ketakutan } \\
\text { dan kekhawatiran }\end{array}$ & 9 & 11,84 & 67 & 88.16 \\
\hline Menyatu (menikmati) dengan keindahan alam & 10 & 13,16 & 66 & 86,84 \\
\hline Lebih disayang orang lain & 12 & 15,79 & 64 & 84,21 \\
\hline
\end{tabular}


Aan Nuraeni: Kebutuhan Spiritual pada Pasien Kanker

Tabel 3 Distribusi Kebutuhan Dimensi Eksistensi Diri pada Kebutuhan Spiritual Pasien Kanker ( $n=76)$

\begin{tabular}{lcccc}
\hline \multicolumn{1}{c}{ Kebutuhan Kedamaian } & Tidak & $\mathbf{( \% )}$ & Ya & (\%) \\
\hline Tinggal di tempat yang tenang dan damai & 64 & 10,53 & 4624 & 89,47 \\
Menemukan kedamaian batin & 64 & 10,53 & 4624 & 89,47 \\
Berbicara dengan orang lain mengenai ketakutan dan kekhawatiran & 81 & 11,84 & 4489 & 7772.1856 \\
Menyatu (menikmati) dengan keindahan alam & 100 & 13,16 & 4356 & 86,84 \\
Lebih disayang orang lain & 144 & 15,79 & 4096 & 84,21 \\
\hline
\end{tabular}

Tabel 4 Distribusi Kebutuhan Dimensi Kebutuhan untuk Memberi pada Kebutuhan Spiritual Pasien Kanker $(n=76)$

\begin{tabular}{lcccc}
\hline \multicolumn{1}{c}{ Kebutuhan untuk Memberi } & Tidak & $\mathbf{( \% )}$ & Ya & (\%) \\
\hline Beralih menjadi orang yang penuh cinta kasih & 8 & 10,53 & 68 & 89,47 \\
Memberikan sesuatu untuk diri sendiri & 11 & 14,47 & 65 & 85,53 \\
Menjadi pelipur lara orang lain & 21 & 27,63 & 55 & 72,37 \\
Lebih disayang orang lain & 144 & 15,79 & 4096 & 84,21 \\
\hline
\end{tabular}

Tabel 5 Distribusi Tingkat/Seberapa Jauh Pentingnya Kebutuhan Spiritual Pasien Kanker $(\mathbf{n}=76)$

\begin{tabular}{lc}
\hline \multicolumn{1}{c}{ Kebutuhan untuk Memberi } & Tidak \\
\hline Beralih menjadi orang yang penuh cinta kasih & 8 \\
Memberikan sesuatu untuk diri sendiri & 11 \\
Menjadi pelipur lara orang lain & 21 \\
\hline
\end{tabular}

satu kebutuhan spiritual mereka, dan aspek "tinggal di tempat yang tenang dan damai serta menemukan kedamaian batin" menjadi aspek yang paling banyak dibutuhkan oleh responden (Tabel 2). "Menemukan makna dalam sakit atau penderitaan" merupakan aspek yang paling banyak dibutuhkan oleh hampir seluruh responden, namun demikian aspek "Menghilangkan Dimensi keterbukaan dalam hidup" paling sedikit dipilih oleh responden, aspek ini tidak dibutuhkan oleh sebagian besar responden (Tabel 3).

Tabel 4 menunjukkan dimensi ini sebagian besar dibutuhkan oleh responden terutama pada aspek "beralih menjadi orang yang penuh cinta kasih", dan aspek "menjadi pelipur lara orang lain" menjadi aspek yang paling sedikit dipilih dalam dimensi ini, namun demikian tetap saja sebagian besar responden merasakan kebutuhan untuk "menghibur orang lain". Untuk menilai seberapa kuat / penting kebutuhan spiritual digunakan skala 1-3 (1-1,9 agak dibutuhkan; 2-2,9 dibutuhkan; 3 sangat dibutuhkan), berdasarkan skala tersebut seluruh dimensi kebutuhan spiritual berada pada kategori dibutuhkan, dan berdasarkan tingginya nilai rerata maka dimensi religi menjadi dimensi kebutuhan spiritual yang paling dibutuhkan dibanding dimensi spiritual lainnya (Tabel 5).

\section{Pembahasan}

Kebutuhan spiritualitas merupakan kebutuhan yang penting untuk dipenuhi pada pasien dengan penyakit kanker selain aspek kebutuhan lainnya, karena penyakit ini dapat berdampak terhadap seluruh aspek kehidupan penderitanya baik fisik, psikologis maupun spiritual. Spiritualitas menurut Puchalski (2001) dapat digunakan sebagai salah satu sumber koping selain itu spiritualitas memberikan dampak yang 
positif bagi kesehatan dan dapat dijadikan sebagai sumber penyembuhan (healing). Hal ini diperkuat oleh hasil penelitian Bussing et al (2010) bahwa sebagian besar pasien kanker memerlukan spiritualitas ataupun religiusitas sebagai sumber koping untuk menghadapi kondisi tersebut, sehingga pengetahuan yang baik tentang kebutuhan spiritual pasien oleh perawat menjadi penting untuk dimiliki.

Menurut Bussing et al (2010) kebutuhan spiritual meliputi: kebutuhan religi atau keagamaan; kebutuhan mendapatkan kedamaian; eksistensi diri; serta kebutuhan untuk memberi. Setiap orang memiliki kebutuhan ini namun demikian berbeda dalam aspek maupun tingkat kebutuhannya masingmasing, sehingga penting untuk dilakukan kajian terlebih dahulu dalam menentukan kebutuhan spiritual pasien.

Berdasarkan hasil penelitian dapat diketahui bahwa kebutuhan keagamaan/religi menjadi kebutuhan spiritual yang paling banyak dibutuhkan oleh responden diikuti oleh kebutuhan eksistensi diri. Kebutuhan mendapatkan kedamaian serta kebutuhan untuk memberi memiliki jumlah persentase yang hampir sama namun berada dibawah kebutuhan eksistensi. Secara umum seluruh kebutuhan ini dipilih oleh sebagian besar responden, sehingga dapat disimpulkan bahwa seluruh kebutuhan ini penting untuk diperhatikan dan diupayakan pemenuhannya.

Dilihat dari tingkatan sampai seberapa penting pemenuhan kebutuhan spiritual, kebutuhan religi/keagamaan menjadi kebutuhan yang dibutuhkan dibanding kebutuhan spiritual pada dimensi lainnya, hal ini berdasarkan pada nilai rerata yang diperoleh pada masing-masing dimensi. Seberapa penting tingkatan kebutuhan spiritual pada dimensi lainnya secara berurutan dituliskan sebagai berikut: dimensi kedamaian; dimensi eksistensi diri dan dimensi kebutuhan untuk memberi.

Dimensi kebutuhan keagamaan/religi menjadi kebutuhan yang paling banyak dibutuhkan serta menjadi kebutuhan spiritual yang dibutuhkan oleh responden dibandingkan dimensi lainnya, hampir seluruh responden membutuhkan kebutuhan spiritualitas ini. Dengan aspek (item) kebutuhan berdoa dengan orang lain serta didoakan oleh orang lain menjadi aspek kebutuhan yang paling banyak dipilih oleh responden. Hal ini semakin memperlihatkan bahwa dalam masyarakat Indonesia khususnya Jawa Barat kebutuhan religi atau keagamaan memegang peranan penting dalam kehidupan. Hal ini diperkuat oleh Suryaman (2011) yang menyatakan bahwa masyarakat Jawa Barat atau Sunda dikenal sebagai masyarakat religius. Kebudayaan masyarakat Sunda pun banyak dipengaruhi oleh budaya Islam. Hal ini diperkuat oleh Agoes (2003) bahwa agama Islam merupakan agama yang telah lama dipeluk oleh masyarakat Sunda, maka sulit untuk memisahkan adat dan agama karena biasanya kedua unsur tersebut sudah menyatu menjadi adat kebiasaan dan kebudayaan orang Sunda.

Masyarakat Sunda dinyatakan oleh Suryaman (2011) memiliki pandangan setiap kali dihadapkan pada kesulitan yakni walaupun jasmani sakit namun rohani harus tetap sehat, yakni sehat dalam berbuat dan bertindak, sehat berpikir dan berprasangka. Sehat berprasangka berarti menjauhkan pikiran dari sifat suudzon (berprasangka buruk) terutama kepada Tuhan sehingga walaupun dihadapkan dengan kesulitan tetap dapat melihat hikmah dan berbagai sisi positif dari sakit yang dialami, dan meyakini bahwa Tuhan yang mengatur seluruh kehidupan manusia. Menurut Nuraeni (2012) spiritualitas bagi pasien dapat berarti penerimaan dan kepasrahan kepada Tuhan namun disertai dengan usaha dan ikhtiar untuk mendapatkan kesembuhan, dalam penelitian ini salah satu bentuk ikhtiar yang dilakukan adalah melaui berobat dan terus berdoa, kebutuhan spiritual dari dimensi religi yang dianggap sangat amat sangat dibutuhkan pada pasien kanker dalam penelitian ini adalah berdoa, baik untuk diri sendiri maupun didoakan oleh orang lain.

Terkait dengan keyakinan ini, perawat sebagai tenaga kesehatan yang selama 24 jam mendampingi pasien perlu membantu pasien dalam memenuhi kebutuhan akan keagamaannya, hal ini dapat dipenuhi dengan kegiatan sederhana seperti berdoa bersama dengan pasien, menyediakan buku-buku keagamaan, dan memfasilitasi ibadah pasien.

Selanjutnya adalah kebutuhan akan kedamaian (inner peace) menurut Chao, 
Chen dan Yen (2002) kedamaian diri adalah spiritualitas yang muncul dari rekonsiliasi pada diri sendiri, sebagai hasil dari negosiasi terhadap konflik yang dihadapi. Menurut Chao et al (2002) setiap orang disepanjang hidupnya pasti pernah merasakan inferioritas, tidak percaya diri, egois, malu bahkan benci terhadap diri sendiri, dan kedamaian dapat muncul dari self reconciliation terhadap masalah yang dialami, sehingga mampu memberikan penghargaan yang baik bagi diri sendiri. Dalam penelitian Nuraeni (2012) kedamaian diri dapat muncul sebagai bentuk penerimaan terhadap permasalahan (penyakit) yang dianggap sebagai teguran maupun cobaan, penerimaan ini dapat membawa kedalam kehidupan yang lebih baik.

Menurut Bussing et al (2010) kebutuhan akan kedamaian antara lain terdiri dari aspek berikut ini : berharap berada ditempat yang tenang dan sunyi, menikmati keindahan alam, menemukan kedamaian dari dalam, berbicara dengan orang lain tentang ketakutan dan kekhawatiran, dan ketaatan. Pemenuhan kebutuhan akan kedamaian ini pada sebagian responden masih belum terpenuhi. Berdasarkan uraian yang sudah disebutkan sebelumnya pemenuhan kebutuhan kedamaian ini dapat dilakukan oleh perawat melalui beberapa hal, yakni : fasilitasi tempat yang tenang dan sunyi, memberikan waktuwaktu tertentu bagi pasien untuk menyendiri serta mendorong penerimaan pasien akan penyakitnya, selain itu perawat juga dapat mendekatkan pasien dengan alam dengan cara menambahkan ornamen alam di ruang rawat dapat melaui suara gemericik air, lukisan tentang alam dan sebagainya.

Kebutuhan spiritualitas pada dimensi kebutuhan eksistensi diri menjadi kebutuhan spiritual selanjutnya setelah kebutuhan dalam dimensi kedamaian diri. Kebutuhan eksistensi diri menurut Bussing et al (2010) meliputi refleksi kehidupan, berbicara dengan seseorang tentang arti dan makna kehidupan, berbicara dengan seseorang tentang ketakutan, dan kehidupan setelah kematian. Frankl (dalam Guillory et al, 1997) menyatakan bahwa inti dari keberadaan seorang manusia (eksistensi) adalah melalui pencarian makna dan tujuan hidup. Lebih jauh Buchardt dan
Nagai-Jacobson mendefinisikan spiritualitas sebagai esensi dari keberadaan manusia, menanamkan kesadaran tentang siapa kita, apa tujuan hidup dan sumber batin seorang manusia. Pemenuhan kebutuhan eksistensi diri dalam penelitian ini masih rendah jika dibandingkan dengan pemenuhan kebutuhan religi dan kebutuhan untuk memberi. Perawat dapat membantu pasien untuk memenuhi kebutuhan eksistensi diri pasien melalui komunikasi ataupun memfasilitasi dan mendorong pasien dalam hal melakukan interospeksi diri, berbicara tentang makna dan tujuan hidup, makna sakit dan penderitaan serta kehidupan setelah kematian.

Dimensi kebutuhan spiritual yang terakhir adalah kebutuhan untuk memberi. Dibandingkan dmensi kebutuhan spiritual sebelumnya, kebutuhan spiritual ini dirasakan penting namun dalam tingkat yang lebih rendah. Menurut Bussing et al (2010) kebutuhan untuk memberi terdiri dari :secara aktif dan atas kesadaran sendiri menghibur orang lain, untuk berbagi pengalaman kepada orang lain, dan untuk memastikan bahwa hidup ini memiliki nilai dan makna. Hal ini memperkuat penelitian yang dilakukan oleh Walton (2002) bahwa spiritualitas adalah keseimbangan, setelah seseorang mendapatkan bantuan, pertolongan dari orang lain pada saat mengalami krisis, akan timbul keinginan untuk dapat memberi atau berguna bagi orang lain, agar dia mendapatkan keseimbangan. Pendapat ini diperkuat juga oleh Nuraeni (2012) bahwa salah satu makna spiritualitas pada pasien sakit di Indonesia adalah memberi manfaat bagi sesama.

\section{Simpulan}

Perawat memiliki peran sebagai care provider. Dalam menunaikan perannya perawat harus melihat pasien sebagai satu kesatuan yang holistik. Upaya yang harus dilakukan untuk meningkatkan pelayanan asuhan keperawatan spiritual pada pasien, salah satunya adalah melalui kajian kebutuhan spiritual. Kebutuhan spiritual pada pasien kanker pada penelitian ini meliputi keseluruhan dimensi yang diukur yaitu : kebutuhan religi/keagamaan; kebutuhan kedamaian; eksistensi diri; dan 
kebutuhan untuk memberi. Kebutuhan religi/ keagamaan menjadi kebutuhan spiritual yang paling banyak dibutuhkan oleh pasien kanker. Selain itu kebutuhan eksistensi diri dalam aspek menemukan makna dalam sakit dan penderitaan pun dipilih hampir oleh seluruh responden sedangkan aspek menghilangkan keterbukaan dalam hidup merupakan kebutuhan spiritual yang paling sedikit dipilih. Berdasarkan tingkat/pentingnya kebutuhan spiritual secara umum, seluruh dimensi kebutuhan spiritual penting untuk dipenuhi, dengan tingkatan kebutuhan dari nilai tertinggi sampai terendah adalah sebagai berikut: 1) kebutuhan religi; 2) kebutuhan kedamaian; 3) kebutuhan eksistensi diri; dan 4) kebutuhan untuk memberi.

Religi merupakan kebutuhan spiritual yang dianggap paling penting dan paling banyak dibutuhkan oleh pasien, sehingga pemenuhan kebutuhan ini perlu diperhatikan oleh perawat. Perawat dapat mendukung pemenuhan kebutuhan ini melalui kegiatan sederhana seperti berdoa bersama dengan pasien, menyediakan buku-buku keagamaan, dan memfasilitasi ibadah pasien. Kebutuhan spiritual yang dianggap penting lainnya namun pemenuhannya masih belum optimal adalah kebutuhan kedamaian dan eksistensi diri, untuk mendukung pemenuhan kebutuhan ini perawat dapat melakukan komunikasi teurapeutik yang dapat mendorong pasien untuk introspeksi diri, berbicara tentang makna dan tujuan hidup, makna sakit dan penderitaan serta kehidupan setelah kematian. Selain itu untuk mendapatkan perasaan damai perawat perlu memberikan waktuwaktu tertentu bagi pasien untuk menyendiri jika memungkinkan menciptakan tempat rawat inap yang tenang, selain itu perawat juga dapat mendekatkan pasien dengan alam dengan cara menambahkan unsur alam dalam ruang perawatan dapat melaui suara gemericik air, lukisan tentang alam, bunga dan sebagainya.

\section{Daftar Pustaka}

Agoes, A. (2003). Perkawinan Adat Sunda. Jakarta: Gramedia
Ahn, E., Cho, J., Shin, D. W., Park, B. W., Ahn, S. H., Noh, D.-Y., ... Yun, Y. H. (2009). Impact of breast cancer diagnosis and treatment on work-related life and factors affecting them. Breast Cancer Research and Treatment, 116(3), 609-16. doi:10.1007/ s10549-008-0209-9

Anandarajah, G., \& Hight, E. (2001). Spirituality and medical Practice: using the HOPE questions as a practical tool for spiritual assesment. American Family Physician, 63(1), 81-88.

Ariyani, H., Suryani., Nuraeni A. (2014). Perbedaan Persepsi Perawat dan Pasien Terhadap kebutuhan spiritual Pasien sindrom Koroner Akut. Thesis. Universitas Padjadjaran

Braeken, A.P., et.al. (2009). The effectiveness of the screening inventory of psychosocial problems (SIPP) in cancer patients treated with radiotherapy: design of cluster randomized controlled trial. BMC Cancer, 9, 1471-2407.

Brown, et al. (2005). Gynaecological Cancer Guidance for Nursing Staff. London:Published by the Royal College of Nursing.

Burkhardt, M. A., \& Nagai-Jacobson, M. G. (2005).Spirituality and Health. In Holistic Nursing A Handbook For Practice (Fourth ed.). Massachussetts: Jones And Bartlett Publisher.

Bussing, A., Balzat, H., \& Heusser, P. (2010). Spiritual needs of patients with chronic pain diseases and cancer - validation of the spiritual needs questionnaire. Eur J Med Res 2010, 15, 266-273.

Dossey, B. M., Keegan, L., \& Guzzetta, C. E. (2005).Holistic Nursing : A Handbook for Practice (Fouth ed.). Massachusetts: Jones and Bartlett Publisher Inc.

Grimsbø, G. H., Ruland, C. M., \& Finset, A. (2012). Cancer patients' expressions of emotional cues and concerns and oncology 
nurses' responses, in an online patient-nurse communication service. Patient Education and Counseling, 88(1), 36-43. doi:10.1016/j. pec.2012.01.007.

Guillory, J. A., Sowell, R., Moneyham, L., \& Seals, B. (1997).An exploration of the meaning and use of spirituality among women with HIV/AIDS.Alternative Therapy Health Medicine, 3(5), 55-60.

Hamid, AS. (2009). Bunga Rampai Asuhan Keperawatan Kesehatan Jiwa.Jakarta: Penerbit Buku Kedokteran EGC.

Hawari, D. (2004). Doa dan Dzikir Sebagai Pelengkap. Jakarta: Dana Bhakti Prima Yasa.

Hodge, D.R., Sun, F., Wolosin, R. J. (2014). Hospitalized asian patients and their spiritual needs: Developing a model of spiritual care. Journals of Aging Health. Retrieved 24 Maret 2014, fromhttp://www.ncbi.nlm.nih. gov/pubmed/24420844.

Kociszewski. (2004). Spiritual care: A phenomenologic study of critical care nurses. Heart Lung, 33(6), 401-11. Retrieved 12 September 2013, from http://www.ncbi.nlm. nih.gov/pubmed/15597294.

Lipscomb J., Gotay, CC., \& Snyder, C. (2005).Outcomes Assessment in Cancer Measures, Methods, and Applications.United States: Cambrige University Press.

Lorentz, M. M. (2006). Stress and Psychoneuroimmunology Revisited: Using mind-body interventions to reduce stress. Alternative Journal of Nursing (11), 1-11.

Machin, L. (2009). Working With Loss ang Grief. London: SAGE Publication Ltd.

Manajemen RS. (2014). Prevalensi Kanker di Dunia dan Indonesia. Retrieved Desember 1, 2015, from Manajemen Rumah Sakit: http://manajemenrumahsakit.net/2014/01/ prevalensi-kanker-di-indonesia-dan-dunia.

Martz, E., \& Livneh, H. (2007). Coping With Chronic Illness and Dissability Theoretical,
Empirical, and Clinical Aspects. New York: Springer Science + Business Media, LLC.

Mcgrath.(2004). Reflections on serious illness as spiritual journey by survivors of haematological malignancies.European Journal of Cancer Care, 13, 227-237.

Mok, E., Wong, F., \&wong, D. (2009). The Meaning of Spirituality and Spiritual Care Among The Hongkong Chinese Terminally Ill. Journal of Advanced Nursing, 360-370.

Murray, S. A. (2004). Exploring the Spiritual Needs of People Dying of Lung Cancer or Heart failure: A Prospective Qualitative Interview Study of patients and Their carers. Journal of Palliative Medicine pp 18, 3945.

Peterson, SJ., \& Bredow, TS. (2009). Middle Range Theories Application to Nursing Research. United States of America: Wolkers Kluwer Health Lippincott Williams \& Wilkins.

Puchalski. (2001). The role of spirituality in health care. Baylor University medical Center Proceedings, 14(4), 352-357.

Puchalski, C., Virani, R., Otis-Green, S., Baird, P., Bull, J., Chochinov, H., et al. (2009).Improving the Quality of Spiritual Care as a Dimension of Palliative Care: The Report of the Consensus Conference.Journal of Palliative Medicine, 12(10), 885-904.

Roos, S. (2002). Chronic Sorrow A Living Loss. New York: Brunner-Routledge.

Setiawan, N. (2007). Penentuan Ukuran Sampel Memakai Rumus Slovin Dan Tabel Krejcie-Morgan: Telah Konsep dan Aplikasinya. Retrieved Maret 24, 2014, from Pustaka Unpad: http://pustaka.unpad.ac.id/ wp-content/uploads/2009/03/penentuan ukuran_sampel_memakai_rumus_slovin.pdf

Suryaman, B. (2011). Budaya dan Kebudayaan Sunda. Retrieved from http:// www.bengkalis.org/index.php/Budaya/ budaya-dan-kebudayaan-sunda.php. 
Aan Nuraeni: Kebutuhan Spiritual pada Pasien Kanker

Sjamsuhidajat, R., \& Wim de Jong (2004). Grounded Theory Study of Spirituality in Buku Ajar Ilmu Bedah cet. 2. Jakarta: ECG. Hemodialysis Patients. Nephrology Nursing Walton, J. (2002). Finding A Balance: A Journal, 29(5), 447-457. 